\title{
PENGARUH BLENDED LEARNING BERBASIS COOPERATIVE LEARNING PADA PERKEMBANGAN KOGNITIF ANAK USIA DINI
}

\author{
M.Tsaqibul Fikri ${ }^{\text {a, }}$, Hidayah ${ }^{\text {b, }}$, \\ ${ }^{a, b}$ Universitas NU Sunan Giri Bojonegoro, Indonesia \\ 1 tsaqibul@sunan-giri.ac.id, ${ }^{2}$ hidayah@gmail.com
}

\author{
Informasi artikel \\ Received: \\ September 7, 2021. \\ Revised : \\ September 13, 2021. \\ Publish : \\ September 23, 2021. \\ Kata kunci: \\ Blended Learning; \\ Cooperative \\ Learning; \\ Pekembangan \\ Kognitif;
}

Keywords: Blended Learning;

Cooperative

Learning;

Cognitive

Development

\begin{abstract}
ABSTRAK
Model pembelajaran blended learning berbasis cooperative learning bisa menjadi salah satu alternatif dalam mengembangkan kognitif anak usia dini, dengan menggunakan berbagai kegiatan yang menarik sehingga anak mampu memecahkan masalah secara kreatif. Penelitian ini memiliki tujuan untuk menganalisis signifikasi pengaruh model blended learning berbasis cooperative learning pada perkembangan kognitif anak usia 3-4 tahun. Metode yang di gunakan dalam penelitian ini adalah Pre eksperimental dengan desain one group Pretest-Posttest. Penelitian ini di laksanakan di KB Al Hikmah Desa Cengkong Kecamatan Parengan Kabupaten Tuban. Waktu melakasanakan penelitian ini pada tanggal 25-27 Februari 2021. Populasi dalam penelitian ini berjumlah 18 anak. Teknik pengambilan sampel menggunakan nonprobability sampling. Teknik pengumpulan data penelitian ini menggunakan observasi dan dokumentasi. Teknik analisi data menggunakan analisis tabel, analisis uni non parametrik dan uji regresi linier sederhana. Hasil penelitian ini menunjukkan ada pengaruh model pembelajaran blenden learning berbasis cooperative learning pada perkembangan kognitif anak usia 3-4 tahun sebelum di beri aktivitas pembelajaran blended learning dan sesudah di beri aktivitas pembelajaran blended learning.
\end{abstract}

\section{ABSTRACT}

The blended learning model based on cooperative learning can be an alternative in developing early childhood cognitive, using a variety of interesting activities so that children are able to solve problems creatively. This study aims to analyze the significance of the effect of the cooperative learning-based blended learning model on the cognitive development of children aged 3-4 years. The method used in this study is Pre-experimental with a one-group pretest-posttest design. This research was carried out at KB Al Hikmah, Cengkong Village, Parengan District, Tuban Regency. The time to carry out this research is on 25-27 February 2021. The population in this study amounted to 18 children. The sampling technique used was non-probability sampling. The data collection technique of this research used observation and documentation. The data analysis technique used table analysis, nonparametric uni analysis and simple linear regression test. The results of this study indicate that there is an effect of the blended learning model based on cooperative learning on the cognitive development of children aged 3-4 years before being given blended learning activities and after being given blended learning activities.

This work is licensed under a Creative Commons Attribution-ShareAlike 4.0 International License. Allows readers to read, download, copy, distribute, print, search, or link to the full texts of its articles and allow readers to use them for any other lawful purpose. 


\section{PENDAHULUAN}

Pandemi Covid-19 sangat berpengaruh pada dunia pendidikan diseluruh dunia khususnya di Indonesia. Menteri Pendidikan dan Kebudayaan (Mendikbud) Nadiem Anwar Makarim menerbitkan Surat Edaran Nomor 4 Tahun 2020 tentang Pelaksanaan Pendidikan dalam Masa Darurat Coronavirus Disease (Covid-19). Salah satu pokok penting terkait belajar dari rumah ialah aktivitas dan tugas pembelajaran dapat bervariasi antar siswa, sesuai minat dan kondisi masing-masing, termasuk dalam hal kesenjangan akses atau fasilitas belajar di rumah. Adanya Covid-19 mengharuskan semua lembaga pendidikan untuk menggunakan sistem pembelajaran Daring. Menurut (Mediawati dalam Pohan 2020), memandang bahwa pembelajaran Daring ialah wujud dari pendidikan formal yang diterapkan oleh pihak sekolah selama masa pandemi berlangsung yang mana pendidik dan anak tidak dalam satu tempat yang sama, melainkan berada di tempat yang berbeda dan pembelajarn Daring ini bisa dilaksanakan kapan saja dan dimana saja.

Menurut (Isman dalam Dewi 2020), mendefinisikan pembelajaran Daring adalah penggunaa jaringan internet selama proses pembelajaran berlangsung. Melalui sistem pembelajaran Daring anak mempunyai kebebasan waktu belajar, bisa dilakukan kapanpun dan dimanapun, komunikasi dalam pembelajaran Daring bisa melalui beberapa aplikasi, diantaranya: google classroom, video, converence, telepon, live chat, zoom, ataupun wa group. Pembelajaran Daring untuk anak usia dini sangat berbeda dengan pembelajaran Daring tingkat pendidikan lainnya, pasalnya pembelajaran Daring untuk anak usia dini orang tua sangat berperan aktif dalam membantu dan membimbing selama proses belajar berlangsung. Anak usia dini tidak akan bisa melakukan kegiatan pembelajaran Daring secara mandiri karena mereka mempunyai sebuah motivasi untuk melaksanakan sesuatu hal yang baik dan bisa beradaptasi pada suatu masalah yang di hadapinya.

Proses pembelajaran dari rumah yang dilaksanakan secara Daring bertujuan untuk memenuhi standard pendidikan melalui pemanfaatan Teknologi Informasi dengan menggunakan perangkat komputer atau gadget yang saling terhubung antara siswa dan guru. Teknologi Informasi yang bisa dimanfaatkan dalam pembelajaran Daring ialah google classroom, youtube, zoom dan whatsapp group. Pembelajaran 
Daring di lakukan oleh semua Lembaga yang ada di Indonesia mulai dari tingkat yang tertinggi yaitu perguruan tinggi hinga ketingkat paling dasar anak usia dini. Beberapa penelitian menunjukkan bahwa pembelajaran Daring pada masa pandemi Covid-19 kurang maksimal untuk anak usia dini.

Model pembelajaran untuk anak usia dini memiliki potensi permasalahan yang beragam dan berbeda antara satu dengan yang lainnya. Dengan adanya permasalahan yang beragam diperlukan stimulasi pada semua aspek perkembangan khususnya aspek perkembangan kognitif, supaya di kehidupan/pendidikan selanjutnya anak mampu menyelasaikan masalahnya sendiri dan mampu berfikir secara dewasa. Salah satu aspek yang perlu dikembangkan pada anak usia dini ialah aspek perkembangan kognitif.

Perkembangan kognitif adalah suatu proses berfikir, dimana anak mampu menunjukkan kemampuan menghubungkan, menilai serta mempertimbangkan suatu kejadian atau peristiwa. Pengembangan kognitif pada anak usia dini bertujuan untuk mengembangkan sebuah kemampuan berfikir anak dalam hal mengolah apa yang di peroleh dari proses belajar, membantu mengembangkan logika dan pengetahuan anak tentang ruang dan waktu, anak di latih untuk memilah, mengelompokkan, serta menyiapkan kemampuannya secara teliti, (Suyadi, 2013).

Kemampuan berpikir anak memiliki tahapan masing-masing, menurut perkembangan kognitif Piaget terdapat empat tahapan yaitu Sensorimotor, praoperasional, operasional konkrit, operasional formal, melihat hal itu setiap perkembangan memiliki hambatan dan setiap Lembaga memiliki permasalahan perkembangan kognitif yang berbeda. Contoh kegiatan untuk menstimulus perkembangan kognitif kemampuan berfikir anak usia 3-4 tahun ialah mengelompokkan benda sesuai warna, membedakan besar kecil bola, membedakan warna. Oleh sebab itu di dunia Pendidikan anak usia dini membutuhkan fasilitas untuk mendukung perkembangannya serta harus melakukan stimulus secara optimal agar kemampuan anak mampu berkembang sesuai dengan tahap usianya.

Berdasarkan observasi awal pada tanggal 02 Agustus 2020 di masa pandemi Covid-19 lembaga KB Al Hikmah menerapkan model pembelajaran Daring akan tetapi tidak semua pembelajaran yang sesuai tema mampu dilakukan secara Daring. 
Pembelajaran di KB Al Hikmah dengan tema "lingkunganku” ternyata kurang maksimal, maka keputusan sekolah menggunakan blended learning berbasis cooperative learning untuk mencapai standart tingkat pencapaian perkembangan anak (STPPA). Blended learning adalah sebuah model pembelajaran yang menggabungkan antara pembelajaran tatap muka (face to-face) dengan e-learning Blended learning merupakan konsep baru dalam pembelajaran dimana penyampaian materi dapat dilakukan di kelas dan online. (Graham dalam Husama 2011) menyebutkan blended learning adalah pembelajaran yang menggabungkan modelmodel pembelajaran dan teori-teori pembelajaran, selain itu juga menggunakan pembelajaran tatap muka (face-to-face) dan pembelajaran online.

Menurut (Rovai and Jordan dalam Hurhadi 2003), Model blended learning pada dasarnya merupakan gabungan keunggulan pembelajaran yang dilakukan secara tatap muka (face to face learning) dan secara virtual (e-learning). Pembelajaran online atau e-learning dalam blended learning menjadi perpanjangan alami dari pembelajaran ruang kelas tradisional yang menggunakan model tatap muka (face to face learning). Berdasarkan teori diatas blended learning adalah suatu model pembelajaran yang pendekatannya fleksibel dimana dalam merancang program yang mendukung bisa digunakan diberbagai tempat dan kapan saja. Lewat model blended learning yang akan digunakan ialah pembelajaran tatap muka berbasis cooperative learning. Setiap kelas bisa diterapkan pengelompokkan peserta didik atau disebut dengan cooperative learning dimana kegiatan belajar mengajar dalam kelompok kecil, siswa belajar dan bekerjasama untuk sampai pada pengalaman belajar yang optimal baik pengalaman individu maupun kelompok.

Peneliti memilih model cooperative learning karena dengan pembagian kelas pada saat musim pandemi seorang guru bisa lebih fokus dalam mengajar juga mengikuti kondisi saat ini. Cooperative learning memiliki banyak manfaat bagi perkembangan anak. Ketika seorang menggunakan blnded learning berbasis cooperative learning seorang guru mampu mengenali capaian perkembangan anak, selain itu ketika perkembangan anak mengalami keterlambatan selama proses pembelajaran dari rumah seorang guru bisa menstimulus ketika bertatap muka. Hasil observasi yang dilakukan ada beberapa permasalahan di KB Al Hikmah salah 
satunya ialah perkembangan kognitif sehingga menjadi bahan penelitian. Terdapat banyak hal yang membuat perkembangan kognitif seorang anak usia dini berkembang pada masa pandemi Covid-19 salah satunya yaitu bisa menggunakan model pembelajaran blended learning berbasis cooperative learning.

(Emria Fitri, 2016) Menjelaskan bahwa model pembelajaran blended learning efektif meningkatkan motivasi belajar siswa, alasanya layanan informasi dengan menggunakan model ini bisa membekali siswa tentang pengetahuan data, fakta dalam pendidikan, dan perkembangan sosial supaya siswa mampu mengatur dan merencanakan hidupnya. Hal ini tentu membuat eksistensi model pembelajaran blended learning dimasa pandemi Covid-19 diketahui oleh masyarakat luas. Model belajar blended learning bisa memberikan lingkungan belajar yang sesuai dengan gaya belajar masing-masing anak dan berfungsi untuk menstimulus aspek perkembangan anak khususnya kemampuan kognitif dalam hal memecahkan masalah

Berdasarkan uraian tersebut, maka peneliti tertarik untuk mengetahui bagaimana pengaruh model blended learning terhadap perkembangan kognitif anak usia 3-4 tahun pada masa pandemi.

\section{METODE}

Pola penelitian ini menggunakan pedekatan kuantitatif. Penelitian kuantitatif adalah suatu proses menemukan sebuah pengetahuan yang menggunakan data berupa angka sebagai alat menemukan keterangan mengenai apa yang ingin kita ketahui. Penelitian kuantitatif dilakukan untuk mengukur hubungan (korelasi, pengaruh) antara dua variabel dan lebih. Jenis penelitian yang digunakan dalam penelitian ini adalah penelitian eksperimen.

Desain penelitian ini peneliti menggunakan Pre Eksperimental design. Di katakan Pre-Eksperimental design karena dalam desain ini tidak ada variabel kontrol dan sampel tidak dipilih secara random.Pre eksperimantal design yang digunakan peneliti ialah one group pretest-postest design. one group pretest-postest design ialah desain yang adanya pretest (sebelum diberi perlakuan) dan posttest (sesudah adanya perlakuan) dengan demikian hasil perlakuan dapat diketahui lebih 
akurat karena dapat membandingkan keadaan sebelum diberi perlakuan dan sesudah diberi perlakuan.

Berikut gambaran rancangan pelaksanaan penelitian Pre Eksperimental design dengan pola One-Group Pretest-Posttest.

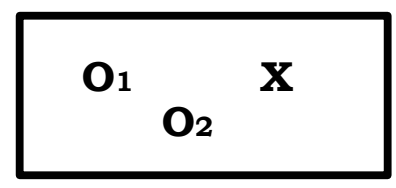

Gambar Rancangan posttest-only control design.

Keterangan :

O1 : Nilai Pre-test (sebelum diberi perlakuan)

$\mathrm{X}$ : Blended learning berbasis cooperative learning (kelas eksperimen)

O2 : Nilai Posttest (setelah diberi perlakuan)

Populasi dalam penelitian ini adalah anak kelompok B KB Al Hikmah Desa Cengkong Kecamatan Parengan Kabupaten Tuban tahun ajaran 2020/2021 yang berjumlah 18 anak. Penelitian ini menggunakan teknik sampling nonprobability sampling dimana ketika mengambil sampel tidak memberi peluang atau kesempatan bagi setiap unsur anggota populasi untuk di pilih menjadi sampel. pengambilan sampel pada penelitian ini menggunakan sampel jenuh, dimana teknik penentuan sampel di ambil dari semua anggota populasi di gunakan sebagai sampel. Hal ini sering di lakukan apabila jumlah populasi yang relatif kecil, kurang dari 30 orang, atau peneliti yang ingin membuat generalisasi dengan kesalahan yang sangat kecil. Pertimbangan lain yang digunakan karena terbatasnya jumlah anak dalam lokasi penelitian yang hanya terdapat satu kelas sebagai penelitian. Penelitian ini hanya mengambil sampel satu kelas yaitu anak kelompok B sebagai kelompok eksperimen dengan jumlah 18 anak, maka bisa di lihat bahwa sampel dalam penelitian ini adalah 18 anak. 
Instrumen penelitian pengaruh metode pembelajaran blended learning berbasis cooperative learning pada perkembangan kognitif anak usia 3-4 tahun

\begin{tabular}{|c|c|c|c|}
\hline Variabel & $\begin{array}{c}\text { Tingkat } \\
\text { Pecampaian } \\
\text { Perkembangan }\end{array}$ & Indikator & $\begin{array}{l}\text { Butir-Butir } \\
\text { Instrumen }\end{array}$ \\
\hline \multirow[t]{4}{*}{$\begin{array}{l}\text { Perkembangan } \\
\text { Kognitif }\end{array}$} & $\begin{array}{l}\text { Menunjukna sikap } \\
\text { kreatif dalam } \\
\text { menyelesaikan } \\
\text { masalah }\end{array}$ & $\begin{array}{l}\text { Cara } \\
\text { menyelesaikan } \\
\text { masalah dengan } \\
\text { kreatif }\end{array}$ & $\begin{array}{l}\text { Mendedakan } \\
\text { angka } 6 \text { dan } 9\end{array}$ \\
\hline & & & $\begin{array}{l}\text { Menyebutkan } \\
\text { kegunaan benda } \\
\text { (pensil, penghaps, } \\
\text { tas ) }\end{array}$ \\
\hline & $\begin{array}{l}\text { Memecahkan } \\
\text { masalah sederhana } \\
\text { dalam kehidupan } \\
\text { sehari-hari }\end{array}$ & $\begin{array}{l}\text { Mengetahui cara } \\
\text { menyelesaikan } \\
\text { gambar yang } \\
\text { kurang lengkap }\end{array}$ & $\begin{array}{l}\text { Mengelompokkan } \\
\text { benda bola atau } \\
\text { leggo sesuai } \\
\text { dengan warnanya. }\end{array}$ \\
\hline & & & $\begin{array}{l}\text { Bereksperimen } \\
\text { dengan warna, } \\
\text { puzzle sekolah }\end{array}$ \\
\hline
\end{tabular}

Pengumpulan data menggunakan observasi dan dokumentasi. Analisis data dalam penelitian ini menggunakan uji hipotesis non parametrik dengan pola kolmogrov-smirnov one sample test dimana menginginkan apakah skor dalam sampel berasal dari populasi memiliki distribusi teoritis. Distribusi teoritis ialah apa yang kita harapkan sesuai dengan Ho dan secara singkat uji K-S mencakup perhitungan distribusi frekuensi kumulatif yang terjadi dibawah distribusi teoritisnya. Analisis data tersebut, dibantu dengan perhitungan yang menggunakan jasa komputer melalui aplikasi IBM SPSS.

\section{PEMBAHASAN}

Observasi atau pengamatan awal dilakukan pada tanggal 02 Agustus 2020 ketika melaksanakan observasi peneliti secara langsung bertemu dengan kepala sekolah dan pendidik KB Al Hikmah desa Cengkong Kecamatan Parengan Kabupaten Tuban. Observasi ini membahas tentang sistem pembelajaran, jumlah pendidik dan peserta didik, sarana prasarana, kurikulum yang dipakai yaitu kurikulum darurat, program unggulan, visi, misi serta tujuan dai $\mathrm{KB}$ Al Hikmah desa Cengkong kecamatan Parengan Kabupaten Tuban. Observasi yang dilakukan peneliti memiliki 
sebuah tujuan untuk mendapatkan gambaran yang jelas tentang subjek penelitian yang ada di lapangan, selain itu juga sebagai bahan pertimbangan agar penelitian ini bisa terlaksana secara maksimal. Di Lembaga KB Al Hikmah Desa Cengkong Kecamatan Parengan Kabupaten Tuban memiliki kendala di kelompok B dimana peserta didik kurang tertarik dengan pembelajaran Daring sehingga perkembangan kognitif dalam hal memecahkan masalah kurang mencapai maksimal. Kognitif dalam memecahkan masalah seperti anak belum mampu membedakan warna, belum mampu menyebutkan kegunaan benda, belum mampu membedakan konsep banyak sedikit, besar kecil serta belum mampu membedakan angka 1-10.

Penelitian ini dilakukan uji coba melalui uji validitas dan reliabilitas. Subjek pelaksanaan yang dilakukan memiliki karakteristik yang sama atau mendekati dengan subjek penelitian yang berjumlah 15 anak sesuai saran dari lembaga. Uji coba instrument penelitian ini dilaksanakan oleh kelompok B usia 3-4 tahun, pada hari 11 Januari 2021, mulai pukul 08:00 WIB sampai 09:00 WIB, dengan durasi waktu 60 menit tanggal dan waktu telah ditentukan oleh lembaga, bertempat di ruamg kelas B KB Subulus Salam Desa Ngujo Kecamatan Kalitidu Kabupaten Bojonegoro.

Penelitian ini menggunakan pedoman observasi yang disusun secara terperinci, lembar pengamatan disi setelah melakukan kegiatan. Instrument penelitian ini di gunakan untuk mengumpulkan data untuk sebuah pertanyaan instrument penelitian dan hipotesis penelitian. Instrumen penelitian sangat menentukan keberhasilan penelitian sehingga bisa mengetahui jawaban dari penelitian dan menguji hipotesis penelitian. Sebelum peneliti melakukan penelitian, maka harus melaksanakan uji coba validitas dan uji reabilitas.

Pengujian validitas dilakukan dengan menggunakan data dari uji coba instrument kelompok kecil. Perhitungan uji validitas instrument penelitian ini peneliti menggunakan bantuan IBM SPSS Statistics versi 22 for windows. Menghitung validitas instrumen digunakan rumus korelasi product moment. Berdasarkan uji validitas dengan melihat kolom pearson correlation di mana dikatakan valid apabila $r$ hitung $>\mathrm{r}$ tabel dengan tingkat signifikan 0,05 (5\%) atau $\mathrm{P}>0.005$. berikut hasil uji validitas instrument pada kelompok kecil. 
Tabel Hasil Uji Validitas Instrumen Penelitian

\begin{tabular}{|l|l|l|l|}
\hline Indikator & $\begin{array}{l}\text { Nilai } \\
\text { Korelasi }\end{array}$ & $\mathrm{R}$ tabel & Keterangan \\
\hline K1 & 0,970 & 0,533 & Valid \\
\hline K2 & 0,913 & 0,533 & Valid \\
\hline K3 & 0,913 & 0,533 & Valid \\
\hline K4 & 0,942 & 0,533 & Valid \\
\hline
\end{tabular}

Berdasarkan hasil uji validitas instrumen penelitian pada tabel 4.3 data dikatakan bahwa nilai perkembangan kognitif $\mathrm{r}$ hitung antara 0,970-0,942 > dari $\mathrm{r}$ tabel 0,553 yang di peroleh dari (n-2) 13 sampel sehingga data tersebut dinyatakan valid.

Uji reliabilitas penelitian menggunakan alpha Cronbach dengan bantuan IBM SPSS Statistick versi 22 for windows. Berikut hasil uji reliabilitas instrument penelitian:

Tabel Hasil Uji Raliabilitas Instrumen Penelitian

\begin{tabular}{|c|l|l|l|}
\hline Variable & Nilai Alpha & Standart & Keterangan \\
\hline $\begin{array}{c}\text { Perkembangan } \\
\text { kognitif }\end{array}$ & 0,848 & 0,6 & Reliabel \\
\hline
\end{tabular}

Berdasarkan tabel diatas bahwa nilai alpha Cronbach 0,848 dan lebih besar dari 0,6 maka data perkembangan kognitif.

\section{Pretest}

Data pretest dilakukan pada subjek penelitian sebanyak satu kali dan dilaksanakan pada tanggal 19 Januari 2021 mulai pukul 08:00 WIB sampai 09:00 WIB, selama 60 menit bertempat di ruang kelas kelompok B KB Al Hikmah Desa Cengkong Kecamatan Parengan Kabupaten Tuban. Pretest ini dilakukan untuk memperoleh data awal mengenai kemampuan perkembangan kognitif pada anak sebelum di beri metode blended learning berbasis cooperative learning. 


\section{Analisis Deskriptif pretest kemampuan kognitif}

\begin{tabular}{|l|l|l|l|l|}
\hline No & Ruang & \multicolumn{1}{|c|}{ Kategori } & Jumlah & Presentase \\
\hline 1. & $4-7$ & Kurang & 3 & $16,8 \%$ \\
\hline 2. & $8-10$ & Cukup & 7 & $38,8 \%$ \\
\hline 3. & $11-13$ & Baik & 8 & $44,4 \%$ \\
\hline 4. & $14-16$ & Sangat baik & 0 & $0 \%$ \\
\hline \multicolumn{3}{|c|}{ Nilai Rata- } & 8,72 \\
\hline \multicolumn{3}{|c|}{ Nilai } \\
\hline
\end{tabular}

Berdasarkan tabel diatas diketahui perkembangan kognitif seorang anak dibagi menjadi 4 bagian atau kategori yaitu kategori kurang, kategori cukup, kategori baik dan sangat baik. Anak yang memperoleh skor 4-7 dengan kategori kurang berjumlah 3 anak 16,8\%. Anak yang mendapat rentang skor 8- 10 dengan kategori cukup berjumlah 7 anak 38,8\%. Kategori baik dengan rentang skor 11-13 berjumlah 8 anak 44,4\%. Pada anak yang mendapat skor 14-16 berjumlah 0 anak $0 \%$. Kesimpulannya perkembangan kognitif anak mayoritas rentang nilai 11-13 dengan kategori baik.

Berdasarkan analisis deskriptif pretest kemampuan kognitif anak pada tabel diatas rata-rata memperoleh nilai 8 yang berada dikategori cukup, nilai tertinggi 12 dengan kategori baik, dan nilai terendah berjumlah 4 dengan kategori kurang. Berikut adalah diagram perbandingan masing-masing kategori. perkembangan kognitif pada saat pretest.

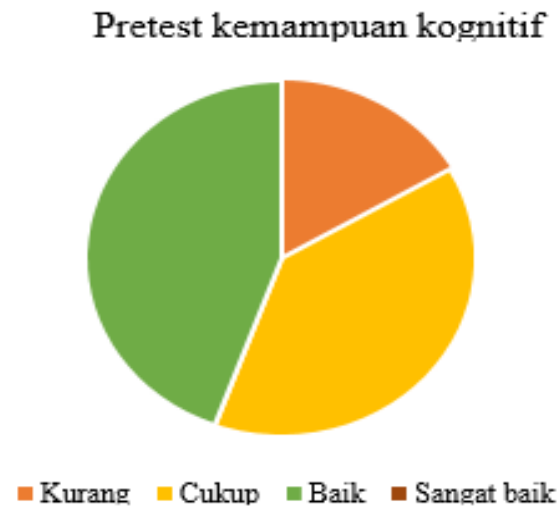

Gambar Diagram Pretest Perkembangan Kognitif 
Pada diagram diatas menunjukkan bahwa nilai pretest perkembangan kognitif mayoritas memiliki nilai baik. Nilai kurang di tunjukkan pada warna orange, nilai cukup di tunjukkan warna kuning, nilai baik ditunjukkan warna hijau dan terakhir nilai sangat baik di tunjukkan warna coklat.

\section{Treatmen}

Pemberian perlakuan (treatment) Perlakuan berlangsung selama 3 hari yaitu pada tanggal 25- 27 Januari 2021. Mengingat masih masa pandemi Covid-19 pelaksanaan treatment dilaksanakan dengan metode blended learning berbasis cooperative learning dimana metode pembelajaran yang menggunakan sistem secara Daring dan Luring. Pembelajaran Luring dilaksanakan dua hari dan satu hari Daring. Selama pembelajaran Luring peserta didik kelompok B KB Al Hikmah Desa Cengkong Kecamatan Parengan Kabupaten Tuban yang berjumlah 18 peserta didik dibagi menjadi 3 kelompok, dimana setiap kelompok terdiri dari 6 anak dan setiap guru memegang satu kelompok. Pembelajaran Luring dilaksanakan selama satu jam mulai pukul 08:00 WIB sampai 09:00 WIB. Treatment secara Luring dilaksanakan diruang kelas dengan pembelajaran evaluasi dan penambahan sedikit kegiatan untuk menstimulus perkembangan kognitif anak usia 3-4 tahub KB $\mathrm{Al}$ Hikmah Desa Cengkong Kecamatan Parengan Kabupaten Tuban. Sedangkan treatmen secara Daring dilaksanakan dirumah dengan kegiatan pemberian kegiatan melalui whatsapp.

\section{Postest}

Data Posttest dilaksanakan pada subjek penelitian sebanyak satu kali pada tanggal 25-26 Februari 2021 mulai pukul 08:00 WIB sampai 09:00 WIB dilakukan secara Luring yang tempat di ruang kelas kelompok B KB Al Hikmah Desa Cengkong Kecamatan Parengan Kabupaten Tuban. Posttest dilaksanakan dengan tujuan untuk memperoleg data mengenai perkembangan kognitif pada anak sesudah diberi metode pembelajaran yaitu blended learning berbasis cooperative learning. Pengambilan data Posttest ini menggunakan instrument penelitian berupa lembar observasi yang telah disusun secara rinci dan menggunakan skor, peneliti tinggal memberikan skor pada kriteria tertentu. 


\section{Tabel Analisis Deskriptif Posttest Kemampuan Kognitif}

\begin{tabular}{|l|l|l|l|l|}
\hline No & Ruang skor & \multicolumn{1}{|c|}{ Kategori } & Jumlah & Presentase \\
\hline 1 & $4-7$ & Kurang & 0 & $0 \%$ \\
\hline 2. & $8-10$ & Cukup & 3 & $16,8 \%$ \\
\hline 3 & $11-13$ & Baik & 7 & $38,8 \%$ \\
\hline 4. & $14-16$ & Sangat baik & 8 & $44,4 \%$ \\
\hline \multicolumn{3}{|c|}{ Nilai Rata-rata } & 11,944 \\
\hline \multicolumn{3}{|c|}{ Nilai terendah } & 15 \\
\hline \multicolumn{5}{|c|}{} \\
\hline
\end{tabular}

Berdasarkan tabel diatas diketahui perkembangan kognitif seorang anak dibagi menjadi 4 bagian atau kategori yaitu kategori kurang, kategori cukup, kategori baik dan sangat baik. Anak yang memperoleh skor 4-7 dengan kategori kurang berjumlah 0 anak 0\%. Anak yang mendapat rentang skor 8-10 dengan kategori cukup berjumlah 3 anak 16,8\%. Kategori baik dengan rentang skor 11-13 berjumlah 7 anak $38,8 \%$. Pada anak yang mendapat skor $14-16$ berjumlah 8 anak 44,4\%. Kesimpulannya perkembangan kognitif anak mayoritas rentang nilai 14-16 dengan kategori sangat baik. Berdasarkan analisis deskriptif posttes kemampuan kognitif anak pada tabel 4.8 rata-rata memperoleh nilai 11,944 yang berada di kategori baik dengan nilai 11, nilai tertinggi 15 dengan kategori sangat baik, dan nilai terendah berjumlah 8 dengan kategori cukup.

Berdasarkan analisis deskriptif pretest kemampuan kognitif anak pada tabel 4.8 rata-rata memperoleh nilai 11,944 yang berada di kategori baik dengan nilai 11 , nilai tertinggi 15 dengan kategori sangat baik, dan nilai terendah berjumlah 8 dengan kategori cukup. Berikut adalah diagram perbandingan masing-masing kategori.

Posttest Kemampuan Kognitif

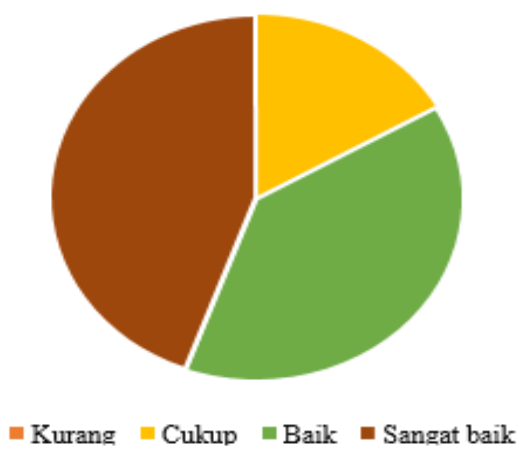

Gambar Diagram Posttest Perkembangan Kognitif 
Diagram diatas menunjukkan nilai Posttest perkembangan kognitif, Posttest digunakan uuntuk mengukur perkembangan kognitif sesudah menggunakan metode blended learning berbasis cooperative learning. Dalam diagram tersebut masyoritas perkembangan kognitif meningkat hal itu di tunjukkan oleh warna hijau menunjukkan baik, warna orange menunjukkan kurang, warna kuning menunjukan cukup dan warna coklat menunjukkan sangat baik.

\section{Uji Hipotesis}

Uji hipotesis penelitian ini menggunakan uji regresi liner sederhana, hal ini digunakan untuk memprediksi atau menguji pengaruh satu variabel bebas atau variabel independent terhadap variabel terikat atau variabel dependen.

Tabel Output Coefficents

\section{Coefficients $^{a}$}

\begin{tabular}{|lr|r|r|r|c|c|}
\hline \multicolumn{1}{|l|}{} & \multicolumn{2}{|c|}{$\begin{array}{c}\text { Unstandardized } \\
\text { Codel }\end{array}$} & $\begin{array}{c}\text { Standardized } \\
\text { Coefficients }\end{array}$ & & \\
1 & B & Std. Error & Beta & $\mathrm{t}$ & Sig. \\
& (Constant) & 4.716 & .819 & & 5.756 & .000 \\
& PRETEST & .829 & .090 & .918 & 9.241 & .000
\end{tabular}

Output bagian keempat Coefficents di ketahui nilai constant (a) sebesar 4,716 sedangkan nilai pretest ( $\mathrm{b}$ atau koefisien regresi) sebesar 0,829 sehingga persamaan regresinya bisa di tulis :

$$
\mathrm{Y}=\mathrm{a}+\mathrm{bX}
$$

$Y=4,716+0,829 X$

Persamaan tersebut bisa di terjemahkan :

1. Konstanta sebesar 4,716 yang memiliki arti nilai variabel posttest sebesar 4,716 .

2. Koefisien regresi $X$ sebesar 0,829 menyatakan bahwa setiap penambahan $1 \%$ nilai pretest maka nilai posttest bertambah 0,829. Koefisien tersebut bernilai positif, di katakana bahwa arah pengaruh variabel $\mathrm{X}$ terhadap $\mathrm{Y}$ adalah positif. 
Pengambilan keputusan dalam uji regresi sederhana :

1) Berdasarkan nilai signifikansi dari tabel Coeficients di peroleh nilai signifikansi sebesar 0,000 $<0,05$ sehingga bisa di simpulkan bahwa blended learning berbasis cooperative learning berpengaruh pada perkembangan kognitif.

2) Berdasarkan nilai $\mathrm{t}$ di ketahui nilai t hitung sebesar 9,241 > t table 2,120 sehingga bisa disimpulkan bahwa model blended learning berbasis cooperative learning berpengaruh pada kemampuan kognitif.

\section{KESIMPULAN}

Penggunaan model blended learning berbasis cooperative learning yang dilakukan dengan tujuan supaya bisa meningkatkan kemampuan kognitif anak sesuai dengan standart tingkat pencapaian perkembangan (STPPA), metode blended learning untuk mengembangkan pengetahuan anak melalui anak membedakan angka 6 dan 9, anak mampu menyebutkan kegunaan pensil, penghapus dan tas, anak mampu menyusun potingan puzzle menjadi sempurna, metode blended learning digunakan oleh pihak sekolah selama satu minggu 2 kali waktu pandemi untuk menstimulus perkembangan kognitif, dengan metode ini bisa membantu dalam meningkatkan perkembangan anak.

Metode blended learning berpengaruh pada perkembangan kognitif berupa: anak mampu membedakan angka 6 dan 9, anak mampu menyebutkan kegunaan pensil, penghapus, dan mampu menyelesaikan puzzle dengan benar. Berdasarkan bab VI, adanya peningkatan skor yang diperoleh dari uji pretest (sebelum perlakuan) rentang skor lebih dominan kurang dalam empat indikator, sedangkan uji posttest (sesudah perlakuan) menunjukkan rentang skor lebih dominan baik dalam empat indicator.

\section{REFERENSI}

A.E, Pohan, Konsep Pembelajaran Daring Berbasis Pendekatan Ilmiah (Jawa Tengah: CV. Sarnu Untung, 2020)

A.F.D, Dewi, 'Dampak Covid-19 Terhadap Implementasi Pembelajaran Daring Disekolah Dasar', Jurnal Ilmu Pendidikan, 2.1 (2020), 56-61 https://doi.org/https://doi.org/10.31004/edukatif.v2i1

A Chaeruman, U, 'Suatu Model Pendidikan Dengan Sistem Belajar Mandiri', Jurnal Teknodik, 2007, 10 
A P Rovai, Jorda H, M, 'Blended Learning and Sense of Community: A Comparative Analysi with Traditional and Fully Online Graduate Courses, International Review of Research in Open and Distance Learning', 5.1492- 3831 (2004)

Abdulhak, Ishak, 'Konseptualisasi Pemetaan Tatanan Kebijakan Serta Sistem Dan Program Pendidikan Anak Dini Usia Di Indonesia', Jurnal Ilmiah Anak Dini Usia Konseptualisasi Sistem \& Program PAUD, 21-46

Adodo \& Agbaweya.J.O, S.O, 'Effect of Homogeneus and Heterogenous Ability Grouping Class Teaching of Students Interest, Attitude and Achievement in Integrated Science, International Journal of Psychology and Counselling', 3 (2011), 48-55 <http://www.academicjournals.org/IJPC/C5BDC0714356>

Amini, Mukti, Perkembangan Dan Konsep Dasar Pengembangan Anak Usia Dini (Tangerang Selatan: Universitas Terbuka, 2014)

Arikunto, Suharsimi, Prosedur Penelitian (Jakarta: Rineka Cipta, 2013)

Bredekamp \& Copple,C, S, Developmentally Appropriate Practice in Early Childhood Programs (Washington: NAEYC, 1997)

Budiyono, Metodelogi Penelitian Pendidikan (Surakarta: Sebelas Maret Universty Pressm, 2003)

C.R., S. Allen, et al, Graham, Benefits And Challenges Of Blended Learning Environments. In M. Khosrow-Pour (Ed.) Encyclopedia of Information Science and Technology I-V. Hershey (Hershey: PA: Idea Group Inc, 2005)

Deklara Nanindya,dkk, Wardani, 'Daya Tarik Pembelajaran Di Era 21 Dengan Blanded Learning', JKTP, Uiversitas Negeri Malang, 1.2615-8787 (2018)

Emria, dkk, Fitri, 'Efektifitas Layanan Informasi Dengan Menggunakan Metode Blanded Learning Untuk Meningkatkan Motivasi Belajar', Jurnal Psikologi Pendidikan \& Konsling, 2.2443-2202 (2016), 84-92

Fitri, Mardi, 'Pengaruh Emergency Remote Learning Untuk Melihat Motivasi Belajar Anak Usia Dini', Child Education Journal, 2.2 (2020), 68-82 https://doi.org/10.33086/cej.v2i2.1591

Ghozali, M.com, Ph.D,Akt, Prof.H.Imam, Statistik NonParametrik (Semarang: UNDIP, 2015)

Hamidi, Metode Peneltian Dan Teori Komunikasi (Malang: UMM Press, 2007)

Husamah, Pembelajaran Bauran (Blenden Laerning) Terampil Memadukan Keunggulan Pembelajaran Face-To-Face, E-Learning Offline-Online, Dan Mobile Learning (Jakarta: Prestasi Pustaka, 2011)

I Amirman Yousda dan Arifin Zainal, Ine, Penelitian Dan Statistik Pendidikan (Jakarta: Bumi Aksara, 1993)

Imron, A, Manajemen Peserta Didik Berbasis Sekolah (Jakarta: Bumi Aksara, 2011)

Isbaniah, Fathiyah, Pedoman Pencegahan Pengendalian Corona Virus Disease (Covid-19) (Jakarta: Kementerian Kesehatan RI, 2020)

Istiningsih dan Hasbullah, Siti, 'Blended Learning Trend Strategi Pembelajaran Masa Depan', Mataram Jurnal Elemen, 1 (2015), 53

J.Bonk, \& Charles R. Graham, Curtis, The Handbook of Blended Learning (USA: Pfeiffer, 2006)

Jarwati, Kurikulum Darurat KB Al Hikmah (Tuban: KB Al Hikmah Desa Cengkong Kecamatan Parengan Kabupaten Tuban, 2020)

Kaye, Thorn, Blended Learning: How to Integrate Online \& Traditional Learning (London: Kagan Page Limited, 2003) 
Mashar, Riana, Emosi Anak Usia Dini Dan Strategi Pengembangan (Jakarta, 2011) $<$ Kencana $>$

Mulyasa, Pengembangan Dan Implementasi Kurikulum (Bandung: Remaja Rosdakarya, 2014)

Musbikin, I, Buku Pintar PAUD (Yogyakarta: Laksana, 2010)

Nafiur Rofiq, M, 'Pembelajaran Kooperatif (Cooperative Learning) Dalam Pengajaran Pendidikan Agama Islam', Jurnal Falasifa, 2010, 1-14

Nakayama M Y, H, 'The Impact of Learner Characterics on Learning Performance in Hybrid Courses among Japanese Students', Elektronic Journal ELearning, 5 (2007), 3

Nurhadi, Pembelajaran Kontekstual Dan Penerapannya Dalam KBK (Malang: Universitas Negeri Malang, 2003)

Peraturan Menteri Pendidikan dan Kebudayaan Republik Indonesia Nomor 137 Tahun 2014, Standar Nasional Pendidikan Anak Usia Dini, 2014

Santos, B, 'Cooperative Learning: Penerapan Tekhnik Jigsaw Dalam Pembelajaran Bahasa Indonesia Di SLTP', Buletin Pelangi Pendidikan, 1.1 (1999), 6

Santrock, J W, Perkembangan Anak (Volume 1) (Jakarta: Erlangga, 2007)

Shofariah, Lailatus, Wawancara Pendidik (Tuban)

Shohib, MA, Dr. H Muhammad, Al Qur'an Dan Terjemahan (Bandung: PT Sygma Examedia Arkanleema, 2007)

Sue (ed), Bredekamp, Developmentally Appropriate Practice in Early Childhood Programs Serving Children from Birth Through Age 8 (Washington: NAEYC, 1992)

Sugiyono, Metode Penelitian Kuantitatif, Kualitatif, Dan R\&D (Bandung: Alfabeta, 2017)

Suyadi \& Dahlia, Implementasi Dan Inovasi Kurikulum Paud 2013, Program Pembelajaran Berbasis Multiple Intelligences (Bandung: PT Remaja Rosdakarya, 2014)

Syaifuddin, Azwar, Metode Penelitian (Yogyakarta: Pustaka Belajar, 2001)

Syaiful, Sagala, Konsep Dan Makna Pembelajaran (Bandung: Alfabeta, 2003)

Syarif, Izuddin, 'Pengaruh Model Blended Learning Terhadap Motivasi Dan Prestasi Belajar Siswa SMK', Jurnal Pendidikan Vokasii, 2.2 (2012), 234-49

T.C, Reluga, 'Game Theory Of Social Distancing In Response To an Epidic' (Plos: Computational Biology, 2010), p. 6

Torrao, S, Blended Learning: Research Report \& Examples of Best Practices (Estonia: University of Tartu, 2007)

Widiasari, Dkk, Santi, 'Play Therapy Berbasis Kearifan Lokal:Peluang Implementasi Teknik Konseling Di Pendidikan Anak Usia Dini', Jurnal CARE (Children Advisory Research and Education ), 04.01 (2016), 61-68

Wulandari, Hesti, and Edi Purwanta, 'Pencapaian Perkembangan Anak Usia Dini Di Taman Kanak-Kanak Selama Pembelajaran Daring Di Masa Pandemi Covid19', Jurnal Obsesi : Jurnal Pendidikan Anak Usia Dini, 5.1 (2020), 452 https://doi.org/10.31004/obsesi.v5i1.626

Y dan Sanan J, Martinis, Panduan Pendidikan Anak Usia Dini (Jakarta: Gaung Perasada, 2010) 